Journal of Money and Economy

Vol. 16, No. 3, Summer 2021

pp. 283-304

DOI: $10.29252 /$ jme.16.3.283

Original Research Article

\title{
An Analysis about the Long Term Impact of Banks Securitization on Economic Growth
}

\author{
Neda Jamshidi* \\ Mahdi Toghyani ${ }^{\ddagger}$ \\ Mohammad Vaez Barzani ${ }^{\dagger}$
}

Received: 23 Nov 2020

Approved: 09 Jan 2022

Economic growth is the most common goal in any economy, and capital is one of the most important determinants of growth. In the last few decades, the use of securities in various countries' capital markets has expanded and has become an essential part of the economic system supplying the capital need for investors and other institutions. This study aims to analyze the effect of securities used to finance banks (securitization) on economic growth. For this purpose, the theoretical analysis method is used in the framework of a Dynamic Stochastic General Equilibrium (DSGE) model. The theoretical model used is based on Frank Ramsey's (1928) economic growth model. To transform this model into a suitable model for research, the shadow banking system and securitization have been added. The model is then simulated using the calibration method and using the real data of the US economy; then, the macroeconomic changes and fluctuations created by bank securities are explained and analyzed. According to the research findings, issuing securities by banks will lead to slower economic growth. Therefore, it is recommended to avoid the use of securitization in banking.

Keywords: Securitization, Banking, Economic Growth, Calibration Method Constructed Financing.

JEL Classification: C63, E44, G21

\section{Introduction}

The importance of capital in the production process is obvious to anyone. Historically, capital used to be the physical instrument of human labour, but today, the accumulation of liquidity to start or continue an economic activity

\footnotetext{
* Department of Economics, University of Isfahan, Isfahan, Iran; Email: n.jamshidi23@gmail.com

$\dagger$ Department of Economics, University of Isfahan, Isfahan, Iran; Email: M.vaez@ase.ui.ac.ir (Corresponding Author)

ॠ Department of Economics, University of Isfahan, Isfahan, Iran; Email:

M.toghyani@ase.ui.ac.ir
} 
is regarded as one of the main inputs for business. The capital comes either from government assets and company owners or through the financing process. Sometimes, banks also face problems with financing and rely on other financial markets for providing resources. There are a variety of methods and tools for financing.

Securities are one of the methods of financing production. Converting bank assets to securities is one of the recently more used tools in financing by reducing the risk of financial institutions. The term securitization is one of the concepts that have been appeared in the financial literature for about two decades. Securitization is the process by which the assets of a firm are first separated from its balance sheet. Then, the investors who have purchased the exchangeable financial instrument supply the capital needed in exchange for those bonds. In this process, the "fundraising company" replaces financial intermediaries such as commercial banks and sells debt securities to investors. A fundraising company collects a set of financial assets and sells debt securities to the investor (as a third party) to fund the financial need of the original owner (Manjoo, 2005: 10).

In other words, the method of financing through securities is fundamentally different from the method of financing by the issuance of commercial papers; that's because; when an institution issues securities, it does so without any backing assets; and by selling securities, the necessary financial resources are provided for that institution. But when a company or bank issues commercial papers, it has had assets first and then issues commercial papers backed by them. Those assets have been removed from the balance sheet of that firm in terms of accounting.

A review of literature about securities clearly shows that there are two economic views on its macroeconomic effects. A group of economists have a positive idea about securities; they believe that the development of securities can improve economic growth by forming new capital. The influencing mechanisms of securities on capital formation are:

1) Stagnant and unused money becomes productive capital by participating in the production.

2) Creating new demand in the commodity market by institutions that use securities funding (Fabozzi \& Kothari, 2008).

3) Reducing financial intermediation costs for institutions that use security resources, compared with financing through conventional methods such as borrowing. 
Another group of economists believes that securities hurt economic growth by reducing capital formation. The negative impact of securities on capital formation are:

1) There may be no correlation between the value of the underlying assets and the nominal value of the bonds issued relying on these underlying assets. There is a risk that banks or institutions that collect resources in this way collect resources that do not rely on real assets, and this amount of resources could create price bubbles by creating money. The spread of uncertainty due to the effects of the asset bubble harms economic growth. Securities can increase the money supply and inflation by reducing bank surpluses, and new inflation can hurt economic growth by creating macro risk.

2) Since the risk of issued securities is unknown to buyers, the lack of risk management will lead to a bubble in the price of those securities. In the event of a bubble burst, the inflow of funds to finance capital is suddenly shaken and ultimately leads to a slowdown in economic growth (Stiglitz, 2009).

This group of economists emphasizes the process of creating the financial crisis of 2008, in which the price of the mortgage bubble caused the financial crisis and caused a negative impetus to capital formation and economic growth rate. In other words, they consider the irregular and out-of-financial use of securities the cause of the crisis in the economy. Now, the central question of this research is; what would be the net effect of securities on economic growth.

Therefore, this study, by investigating the effect of securitization in banking on economic growth, seeks to answer how the capital and credit created by securitization in banks affect economic growth?

The United States has historically been a pioneer in securities. We know that the 2008 financial crisis began in the US economy; therefore, in this research, the economical parameters of this country are used in simulating the model. The present study is organized as follow; the first section includes introduction. Literature review and research background are represented in the next section. The third and fourth section respectively include methodology of estimation as well as data and summary statistics. We present our conclusions and suggestions in the final section.

\section{Literature Review and Theoretical Background}

Securitization of bank assets was started in the United States in 1970. The US government guaranteed those mortgage-backed securities issued by the National Mortgage Institution. During the early 1980s, a market for asset- 
backed securities in the US began to emerge. A similar market for mortgagebacked real estate securities was started in the UK. In the 1990s, real estate property documents were issued as securities in the United States. At the same time, securities and mortgage-backed securities markets in regional European and British markets have been growing further. Since then, securities have seen tremendous growth, especially in mortgage securities.

At the beginning of the 21 st century, dramatic changes in the world's industrial composition took place. Then, the opening up of some markets such as housing and real estate in the years leading to 2007 had a significant impact on the world financial system. Significant volumes of securities were issued in highly complex, risky, and vague market segments previously considered immature markets. During the years 2000 to 2007, the issuance of collateral obligations increased more than six times worldwide. It led to the financial crisis in the United States of the year 2008. However, the use of securities has not stopped and continues to grow, and the market has seen significant growth in recent years.

The simplest and most basic form of securitization is the process of merging a set of loans or homogeneous financial assets in general and transferring that merger to a company or trust, with the specific purpose of issuing securities backed by the merger to be marketed, and thereby creating a market relationship between borrowers and investors (Feghhi, 2006).

In general, in the securitization process, the institution that needs financing will search for an intermediary company. In order to provide the necessary funds to buy the assets, the intermediary company issues asset-backed securities and supplies them in the market. It pays a bank the money it has obtained from the sale of the securities. Buyers (investors) earn returns from cash flows from financial assets (loans).

The same happens by converting bank assets into securities. The bank lends to its clients and receives instalments on due dates. It then sells its claims to the intermediary company for financing and receives the funds according to the intermediary's rules and regulations. The intermediary also issues securities based on these claims and receives funding through this activity in certain fees.

Some of the literature on the macroeconomic effects of securities is in the context of shadow banking expansion. The literature shows the macroeconomics effects of shadow banking. The relationship between financial development through shadow banking (especially securities) and economic growth has been an important part of the economic debate in recent decades. The growth of shadow banking in advanced economies and its 
various services proves the importance of this sector in those countries. The impact of financial markets and shadow banking on production is so essential that many believe economic growth and productivity cannot be achieved without an efficient financial sector. Accordingly, the relationship between securities and economic growth has attracted the attention of many economists in the last two decades. There is a consensus by economists that increasing access to financial instruments, including securities, will reduce the cost of information and exchange in the economy and will lead to economic growth. Economists such as Fry (1995) and King, and Levine (1993) emphasize the substance of financial markets and their key role in economic development and growth (Zhou \& Tewari, 2018)

Nowadays, shadow banking and securities are gaining more attention among politicians. They believe securities create premium investment opportunities, consolidate savings, and increase business efficiency. In addition, adjusting the number of trade exchanges increases investment opportunities. Then, optimization of resources allocation results in increasing the speed of accumulation of physical and human capital, which leads to economic growth (Zhou \& Tewari, 2020).

In recent years, several empirical studies have been conducted to examine the economic impact of securities. We will review some of those considerable studies.

Zhou and Tewari (2020) used panel data from 28 developed and emerging economies to analyze the relationship between shadow banking and economic growth. For this purpose, they used the GLS panel method. They found a longterm positive relationship between shadow banking and economic growth.

Zhou and Tewari (2018), in a study using panel data from 10 emerging economies, analyze the relationship between securities and economic growth. For this purpose, the Pessaran group method (1999) and Granger causality tests have been used. The results indicate that, in the long run, there is a positive relationship between securities and economic growth; and securities are considered as the reason for economic growth.

Chao et al. (2017), in a study using a three-part general equilibrium model, examine the effects of securities on the actual output of a dual developing economy. The results of this study show that in the short run, the development of securities can increase the social welfare of the economy. However, in the long run, the expansion of securities can widen the wage gap between skilled and unskilled labour due to the over-creating of urban manufacturing enterprises. Therefore, if the impact of the company's entry is strong enough, the economy's real output will decrease. 
In a study, Chen and Zhang (2012) analyzed the interaction of the shadow banking system scale with economic growth. Also, they study the effectiveness of the monetary policy. For this purpose, they use the short-term constraints of the structural vector autoregression model. They use the monthly growth rate as a variable for the effectiveness of the monetary policy, and the monthly GDP growth rate is used as a variable for economic growth. Then, the monthly growth rate of trust loans and loans are used as variables for shadow banking. They believe that the shadow banking system would increase China's economic growth but have no effect on inflation.

Ata and Gong (2014) have written an article, "Securitization, Financial Stability, and Macroeconomics." According to the study results, negative economic growth in the Netherlands has also (among other issues) to do with securities. In this study, considering the different time periods (before and after the financial crisis of the year 2008) and also given the speculation with securities in all these periods, the motivation to allocate capital funds changes, and funds are directed towards consumption rather than investment; consequently, economic growth decrease. Therefore, they advise policymakers that if they intend to revive securities in the country, they should limit the important consequences of this process.

Zandieh and Zandieh (2015), in their article "The Role of Securitization in Economic Growth and Development, emphasizing on Iran Economy," have followed the descriptive-correlation method. The results show a significant relationship between the development of securities markets and the degree of financial freedom in some developed countries relating to their economic growth. Also, there is a significant positive linear correlation between the growth of Islamic securities issuance as structured financing and the index of total economic freedom and the indexes of investment freedom and financing freedom in the developing Muslim countries. Also, the current situation of securities in Iran, compared with the role model countries in developing Islamic countries, has been falling behind.

The hypotheses raised by Zandieh and Zandieh (2015) and Chen and Zhang (2012), and Zhou and Tewari $(2018,2020)$ are fundamentally different from the hypothesis and analysis presented in this paper. The difference is that in their study, the positive effect of securities on economic growth is assumed. But in the present study, this hypothesis will not be included in the model, and the research model will be devoid of this hypothesis. Nevertheless, this study will analyze the effect of securities in domestic banking on economic growth.

It is worth noting that in the aforementioned research, the bank is considered as an intermediary in the securities process, which receives only 
remuneration. But in the present study, the bank is the issuer-owner, and the securities are issued to finance its capital needs. So, the results of this study cannot be compared with those of predecessors'. None of the above studies have considered the impact of securities in the bank (when the bank is the owner-issuer) on economic growth, but in some of these studies, securities have been introduced as an important way of financing by banks because of its short run arousing effect on the economy. However, it should be noted that these studies do not address the real nature of considered capital. Capital that is backed by tangibles is a trustable one, and capital without any asset linked to it (or very remote from) is just "illusionary" capital. Therefore, this study investigates the effect of securities in banking on economic growth in a longterm period.

Hereafter a research model is presented by which we can analyze the effect of securities in banking on economic growth.

\section{Estimation Methodology}

In this study, the effect of securitization of bank assets on economic growth is investigated by the theoretical analysis method. For this purpose, the theoretical framework of Ramsey's (1928) economic growth model is used. This model is a basic model for analyzing financial development's impact on long-term macroeconomic variables, especially economic growth. This template originally is a centralized and continuous model out of which Blanchard and Fisher (1993) have developed a decentralized version. In their model, decision-making is based on the micro factors of the template (Blanchard and Fischer, 1993). Also, Christiano (1991) developed a discontinued version that included money and financial intermediaries (Christiano, 1991: 30). Thereafter, Ebrahimi (2012) has developed the Christiano model to a continuous one, with a few minor adjustments to its assumption.

It should be noted that this article seeks to examine the relationship between securities and economic growth relevant to all countries. These reference models are specifically focused on economic growth; that's the reason for using this method.

The model of the present study is developed by modifying the Ebrahimi model. It is a three-segment decentralized neoclassical monetary paradigm involving households, firms, and banks whose banking structure is based on the principle of partial reserve (common banking). To fit in with the objectives of the study, this structure will be changed to shadow banking, thereby adding securities. After that the model will be solved through an optimal control 
method, explaining the impact of securities on economic growth. In what follows, the Ebrahimi model, as the basic model, will be briefly described.

\subsection{Introducing the Basic Model ${ }^{1}$}

This model is a three-segment decentralized neoclassical monetary paradigm involving households, firms, and banks. In this model, the population size at every moment $N_{t}$ and its growth rate is considered $\eta$ (constant value). It is also assumed that at any given moment, there is as much $H_{t}$ of fiat money in the economy and that new fiat money will be distributed, at the beginning of the period, in a one-way payment, evenly across households. Also, the ratio of statutory reserves is equal to $\tau_{M}$ and banks do not hold any precautionary or operational surplus on statutory reserves in the absence of uncertainty.

In this case, households own a primary asset, including commodities and fiat money. They designate all commodity inventory as first-period capital stock and deposit all their money (for the benefit of the deposit and considering the loss by holding cash $^{2}$ ) in the bank. The bank designates deposited fiat money as legal reserves and lends money (backed by those reserves) to corporations. Using the bank loan, the company leases the physical capital it needs and transfers all money received from the bank to households. Households also add the received money to their bank deposit accounts. Next, the firm uses the resources at its disposal to produce for that period and sell all those products. Households pay for products purchased using bank deposits (principal and interest received) and newly transferred fiat money. They consume some of the purchased goods and add the rest to the capital stock. The firm uses the proceeds to settle the loans and ends the period with zero profit. The bank uses the funds it receives from firms to fulfill its obligations to households, and by the end of the period, all fiat remains with banks. Finally, the "golden bank accumulation rule" derived from this model is as follows:

\footnotetext{
${ }^{1}$ Ebrahimi (2012) has introduced a detailed version of this part of model that can be reviewed to compare the results with the modes in this study.

${ }^{2}$ For simplification we assume that cost of holding money is almost zero; so, we can omit it in our equations. Nevertheless, households keep all their fiat money in banks to avoid that cost.
} 
$f^{\prime}\left(k_{B G R}\right)=\frac{\left(1+i^{l}\right)(\theta+\eta)}{\left(1+i_{t}^{d}\right)}=\frac{\left(1+i^{l}\right)(\theta+\eta)}{1+\left(1-\tau_{M}\right) i^{1}}$

Where $i^{d}$ is the profit (yield) rate on deposits (paid to customers), $i^{l}$ is the profit rate on loans (received from debtors), and $\theta$ is the time preference rate (Ebrahimi \& Vaez, 2012).

\subsection{Extension of the Model (Adding Securitization)}

Based on empirical evidence and findings, in order to increase money creation and credit for greater profits, commercial banks chose a variety of ways (especially off-balanced activities) deviating from the aforementioned regulatory frameworks. They practice "Shadow Banking." Shadow banks are constantly developing financial products and services; they eliminate regulatory constraints. Credit risk transfer, converting assets into securities, off-balance-sheet activities, "creating for distribution," "negotiating at the counters" are used to transfer credit risks between several business parties. The purpose of using these tools is to transfer and manage credit risk. In other words, the purpose is to change the credit risk from a non-liquid and inappropriate for the transaction to a tradable one. Converting Assets into Securities is a process by which the assets of the lending company are separated from the balance sheet of the entity; then, debts are financed by investors who buy exchangeable asset-backed securities without referring to the original owner (Najafi, 2006: 41). Off-balance sheet activity means not displaying an item of assets or liabilities or a financing activity in a company's balance sheet. This item can be a lease, a sub or affiliated entity, or a potential debt such as L / C. "Creation for distribution" is how the lender generates that loan to sell the loan to other organizations or investors. Asset-backed security issuance is an orderly process whereby the financial rights linked to the loans, received credits, and other bank or credit institution claims are integrated, then guaranteed, and finally sold as asset-backed securities. Since this study aims to analyze the effect of securities in banking on economic growth, it is assumed that the conversion of assets into securities is the sole activity of banks' credit creation; securities are the only regulatory speculative activity of banks. Also, it is assumed that the economy is closed, and all factors involved in this process are domestic. In other words, the publisher and the investors of securities operate locally (not internationally), and securities are sold in the country.

In this case, in addition to the aforementioned tasks, the banks also issue securities. Households can also make a profit by buying securities issued by 
the bank; obviously, their decision is based on the difference in profit rates on deposits and securities, but for simplicity, it is assumed that households purchase all securities issued by the bank.

Banks issue debt securities and replace them with other debts. Therefore, banks can recover their resources by securities before the maturity of the previously provided facilities. So, with this action, they will have great ability in creating bank loans and money.

In order to simplify the relationship, the study assumes that banks issue securities only once during the period. Therefore, the volume of securities issued by $\mathrm{j}$ th bank during the period under review is:

$\mathrm{S}_{\mathrm{jt}}^{\mathrm{d}}=\frac{1+\mathrm{i}^{1}}{1+\mathrm{i}^{\mathrm{d}}}\left(1-\tau_{\mathrm{M}}\right) \mathrm{H}_{\mathrm{jt}}^{\mathrm{d}}$

From the aggregation of the above relation and the placement of $H_{t}^{d}$, the large supply of $H_{t}$ equations is as follows:

$S_{t}^{d}=\sum_{j} S_{j t}^{d}=\left[\frac{1+i^{l}}{1+i^{d}}\right]\left(1-\tau_{M}\right) \sum_{j} H_{j t}^{d}=\left[\frac{1+i^{l}}{1+i^{d}}\right] \frac{\left(1-\tau_{M}\right) H_{t}}{\tau_{M}}$

All of these bonds will be bought by households. Thus, despite securities, households no longer only deposit their money in the bank but spend some of it on securities. That is, they will first allocate $S_{t}^{d} \mathrm{~d}$ of their funds to buy securities (since it is assumed that all the bonds the bank issues will be purchased by households), then deposit the remainder in the bank. Therefore, the amount of money that households will spend on purchasing securities issued by the bank is equal to the volume of securities issued by the bank. Also, the amount of loan provided by $\mathrm{j}$ th bank despite securities is as follows:

$L_{j t}^{S} \leq\left(1-\tau_{M}\right) \frac{H_{t}}{\tau_{M}}+S_{j t}^{d}$

Which, with the replacing of $S_{j t}^{d} \mathrm{~d}$ and a bit of simplification, would a typical bank loan be:

$L_{j t}^{S} \leq\left[1+\frac{1+i^{l}}{1+i^{d}}\right] \frac{\left(1-\tau_{M}\right) H_{t}}{\tau_{M}}$

Based on the above relationship, the credit creation capacity of banks increases with the creation of bonds.

Under the assumption of the model, firms take all bank loan supply for rent payments. So the whole received loan goes back to households for purchasing production inputs. On the other hand, despite securities, households no longer 
only deposit their money in the bank but first allocate $S_{t}^{d}$ of their funds to the securities, then deposit the remainder in the bank. So we'll have the bank's constraints following:

$H_{t}^{d}+S_{t}^{d}=L_{t}^{S}+\frac{H_{t}}{\tau_{M}}$

By subtracting $S_{t}^{d}$ from both sides of the equation, we will have:

$H_{t}^{d}=L_{t}^{S}+\frac{H_{t}}{\tau_{M}}-S_{t}^{d}$

putting the $L_{t}^{S}$ and $S_{t}^{d}$ in the above relation, we will have:

$H_{t}^{d}=\left[1+\frac{1+i^{l}}{1+i^{d}}\right] \frac{\left(1-\tau_{M}\right) H_{t}}{\tau_{M}}+\frac{H_{t}}{\tau_{M}}-\left[\frac{1+i^{l}}{1+i^{d}}\right] \frac{\left(1-\tau_{M}\right) H_{t}}{\tau_{M}}$

Simplifying the equation, the total household deposit will be as follows:

$H_{t}^{d}=\frac{\left(2-\tau_{M}\right) H_{t}}{\tau_{M}}$

The net profit of the bank can now be obtained based on (5) and (9). Since the bank sells its loans to issue asset-backed securities, the ownership of these loans is taken from the bank, and their profit does not belong to the bank. In other words, when the bank starts issuing securities equal to $\frac{1+i^{l}}{1+i^{d}} \frac{\left(1-\tau_{M}\right) H_{t}}{\tau_{M}}$; he has to sell previous loans as much as $\frac{\left(1-\tau_{M}\right) H_{t}}{\tau_{M}}$. Therefore, the profit on these sold loans no longer belongs to the bank. Accordingly, the net profit equation for a typical bank would be as follows:

$\pi_{j t}^{B}=i{ }_{t}^{l} S_{j t}^{d}-i_{t}^{d} H_{j t}^{d}$

By putting equations (5) and (9) in equation (10), the bank's net profit equation for the securities will be as follows:

$\pi_{j t}^{B}=i_{t}^{l}\left[\frac{1+i^{l}}{1+i^{d}}\right] \frac{\left(1-\tau_{M}\right) H_{t}}{\tau_{M}}-i_{t}^{d}\left[\frac{\left(2-\tau_{M}\right) H_{t}}{\tau_{M}}\right]$

The output of this equation will be the profit of securities for the banks.

In this model, given the competitive nature of the banking industry, the determination of $i_{t}^{d}$ by the monetary authority and the legal requirement of banks to accept customer deposits, $L_{j t}^{S}$ is the only variable for firms in their 
decision-making. In this case, the condition for the banks to maximize their profits is as follows.

$L_{j t}^{S}=\left[1+\frac{1+i^{l}}{1+i^{d}}\right] \frac{\left(1-\tau_{M}\right) H_{j t}}{\tau_{M}}$

$i^{d}=i^{l} \frac{\left(1-\tau_{M}\right)}{\left(2-\tau_{M}\right)}\left[\frac{1+i^{l}}{1+i^{l}-\tau_{M} i^{l}}\right]$

By aggregation of Equation (12), the total supply of loans will be as follows:

$L_{t}^{S}=\sum_{j} L_{j t}^{S}=\left[1+\frac{1+i^{l}}{1+i^{d}}\right] \frac{\left(1-\tau_{M}\right)}{\tau_{M}} \sum_{j} H_{j t}=\left[1+\frac{1+i^{l}}{1+i^{d}}\right] \frac{\left(1-\tau_{M}\right) H_{t}}{\tau_{M}}$

According to Equation (14), most credit supply is an inverse function of the legal deposit ratio and the profit rate on deposits and is directly related to the profit rate on bank loans.

So, considering the loan supply, the following equation can hold;

$\frac{\partial L_{t}^{S}}{\partial \tau_{M}}=-\frac{1}{\tau_{M}^{2}}\left[1+\frac{1+i^{l}}{1+i^{d}}\right] H_{t}<0$

$\frac{\partial L_{t}^{S}}{\partial i^{d}}=\frac{-\left(1+i^{l}\right)}{\left(1+i^{d}\right)^{2}} \frac{\left(1-\tau_{M}\right)}{\tau_{M}} H_{t}<0$

$\frac{\partial L_{t}^{S}}{\partial i^{l}}=\frac{1}{\left(1+i^{d}\right)} \frac{\left(1-\tau_{M}\right)}{\tau_{M}} H_{t}>0$

Therefore, lowering the legal deposit ratio, lowering the profit rate on deposits, and increasing profit rates on loans will increase credit. In other words, increasing securities will increase the supply of credit. In this situation, the level of prices and the real sector (production and per capita capital) will be affected.

Since firms, despite the securitization process, continue their previous activities, that is, by using the resources at their disposal, they produce and sell all the products and, based on the model's assumption, take the hole creditsupply to pay the rent. Accordingly, the net earnings stream (profit) of a typical firm in each period is as follows:

$\pi_{t}^{F}=\frac{1}{N^{F}}\left[P_{t} F\left(K_{t}, N_{t}\right)-\left(1+i_{t}^{l}\right) r_{t} K_{t}-w_{t} N_{t}\right]$

Where simply because of the increase in loan volume, $r_{t} K_{t}$ will be different from its predecessor (equal to $l_{t}^{S}$ ) which does not affect the firm's profit 
equation form. Accordingly, the first-order conditions for maximizing the profits of firms (investment projects) are as follows ${ }^{1}$ :

$\frac{\partial \pi}{\partial K_{t}}=0 \rightarrow P_{t} f^{\prime}\left(k_{t}\right)-\left(1+i_{t}^{l}\right) r_{t}=0 \rightarrow f^{\prime}\left(k_{t}\right)=\left(1+i_{t}^{l}\right) \frac{r_{t}}{P_{t}}$
$\frac{\partial \pi}{\partial N_{t}}=0 \rightarrow P_{t}\left[f\left(k_{t}\right)-k_{t} f^{\prime}\left(k_{t}\right)\right]-w_{t}=0 \rightarrow f\left(k_{t}\right)-k_{t} f^{\prime}\left(k_{t}\right)=\frac{w_{t}}{P_{t}}$

It can be seen that the relationships between the corporate and entrepreneurial sectors will not change. The increasing volume of lending, prices, and capital leasing will be different from before, which does not affect the form of equations.

On the other hand, since the firm borrows only for rent payments, the following equation should always be established, and so we'll have the firm's constraints following:

$l_{t}^{d}=k_{t} r_{t}$

Where $l_{t}^{d}$ is the demand for corporate loans per capita. In this case, in order to have equilibrium in the loan market, it is necessary:

$l_{t}^{d}=k_{t} r_{t}=\left[1+\frac{1+i^{l} l}{1+i^{d}}\right] \frac{\left(1-\tau_{M}\right) H_{t}}{\tau_{M}}=l_{t}^{s}$

By dividing the sides of the relation (22) by $k_{t}$ we will have:

$r_{t}=\frac{\left[1+\frac{1+i^{l}}{1+i^{d}}\right] \frac{\left(1-\tau_{M}\right) H_{t}}{\tau_{M}}}{k_{t}}$

Based on the above equation, capital rent price will increase because of securities.

On the other hand, in addition to their previous activities, households purchase securities issued by the bank and thus earn money. Given that households (using all of their earnings) first buy all the bonds issued by the bank, then spend the rest of their money on deposit, so the household budget constraint will be as follows:

\footnotetext{
${ }^{1}$ Due to the lack of capital adjustment costs in the investment process, there were no interim factors underlying the firm's decision. Hence, the firm only maximizes the profits of each period. Otherwise, the firm should have maximized the discounted sum of all future periods.
} 
$c_{t}+\frac{d k_{t}}{d t}+\eta k_{t}=\frac{H_{t}^{d}\left(1+i^{d}\right)}{P_{t}}+\frac{\left(1+i^{S}\right) S_{t}^{d}}{P_{t}}+\frac{w_{t}}{P_{t}}$

Where $i^{s}$ is profit rate of securities.

It is assumed that the risk intensity of the securities equals that of the deposit in the bank. Therefore, in the long run, the profit rate on the securities is equal to the profit rate on the bank deposit. Holding on to this assumption and putting Equation (7) in (24), we will have:

$c_{t}+\frac{d k_{t}}{d t}+\eta k_{t}=\frac{\left[r_{t} k_{t}+\frac{H_{t}}{\tau_{M}}\right]\left(1+i^{d}\right)}{P_{t}}+\frac{w_{t}}{P_{t}}$

Now by factorizing $k_{t}$ from Equation (25), the household budget constraint will be transformed as follows:

$\frac{d k_{t}}{d t}=-c_{t}+\left[\frac{\left(1+i^{d}\right) r_{t}}{P_{t}}-\eta\right] k_{t}+\frac{\frac{H_{t}}{\tau_{M}}\left(1+i_{t}^{d}\right)}{P_{t}}+\frac{w_{t}}{P_{t}}$

Accordingly, the Hamiltonian function of the zero-sum household decision will be as follows:

$H_{t}=u\left(c_{t}\right) \exp (-\theta t)+\vartheta_{t}\left\{-c_{t}+\left[\frac{\left(1+i^{d}\right) r_{t}}{P_{t}}-\eta\right] k_{t}+\frac{\frac{H_{t}}{\tau_{M}}\left(1+i^{d}\right)+w_{t}}{P_{t}}\right\}$

Putting $\vartheta_{t}=\lambda_{t} \exp (-\theta t)$ and factorizing for $\exp (-\theta t)$, we will have:

$H_{t}=\left\{u\left(c_{t}\right)+\lambda_{t}\left(-c_{t}+\left[\frac{\left(1+i^{d}\right) r_{t}}{P_{t}}-\eta\right] k_{t}+\frac{\frac{H_{t}}{\tau_{M}}\left(1+i^{d}\right)+w_{t}}{P_{t}}\right)\right\} \exp (-\theta t)$

Therefore, the conditions for maximizing consumer utility will be based on the following equations:

$H_{C}=0 \rightarrow u^{\prime}\left(c_{t}\right)=\lambda_{t}$

$H_{k}=-\frac{d \vartheta_{t}}{d t} \rightarrow \frac{d \lambda_{t}}{d t}=\lambda_{t}\left(\theta+\eta-\frac{\left(1+i^{d}\right) r_{t}}{P_{t}}\right)$

$\lim _{t \rightarrow \infty} k_{t} \vartheta_{t}=0 \rightarrow \lim _{t \rightarrow \infty} k_{t} u^{\prime}\left(c_{t}\right) \exp (-\theta t)=0$

Where $\lambda_{t}$ and $\vartheta_{t}$, respectively, are variables of the "condition similar" and degraded state. The above equations can be simplified and pasted as follows: 
$\frac{d c_{t} / d t}{c_{t}}=\dot{c}_{t}=\sigma\left(c_{t}\right)\left(r_{t}-\theta-\eta\right)=\sigma\left(c_{t}\right)\left\{\frac{\left(1+i^{d}\right) f^{\prime}\left(k_{t}\right)}{\left(1+i^{l}\right)}-\theta-\eta\right\}$

The above equation can be simplified and pasted as follows:

$f^{\prime}\left(k_{S G R}\right)=\frac{\left(1+i^{l}\right)(\theta+\eta)}{\left(1+i^{d}\right)}$

According to Equations (13) and (31), the "golden accumulation" rule would be as follows:

$f^{\prime}\left(k_{S G R}\right)=\frac{\left(1+i^{l}\right)(\theta+\eta)}{\left(1+i^{d}\right)}=\frac{\left(1+i^{l}\right)(\theta+\eta)}{1+i \frac{\left(1-\tau_{M}\right)}{\left(2-\tau_{M}\right)}\left[\frac{1+i^{l}}{1+i^{l}-\tau_{M}{ }^{l}}\right]}$

The above relationship is called the "golden accumulation" of capital under shadow banking conditions, indicating that bank money is not neutral in the present model. Because the most important factor affecting it, $\tau$, affects the optimal amount of per capita capital under stable conditions. In practice, given the steady development of securities $\tau$ is not included in the equation of legal deposit ratio) and the weakening of the monitoring rules and speculative thrive of banks, the desired quantity of deposit ratio is effective. An effective deposit ratio is a proportion of deposits that banks voluntarily maintain and withhold due to their credit market conditions and the degree of their risk aversion. Therefore, considering securitization, the equation will be modified as follow:

$f^{\prime}\left(k_{S G R}\right)=\frac{\left(1+i^{l}\right)(\theta+\eta)}{1+i^{l} \frac{\left(1-\tau_{M}\right)}{\left(2-\tau_{M}\right)}\left[\frac{1+i^{l}}{1+i^{l}-\tau_{e} e^{i}}\right]}$

In this equation, given that $1+i^{l} \frac{\left(1-\tau_{M}\right)}{\left(2-\tau_{M}\right)}\left[\frac{1+i^{l}}{1+i^{l}-\tau_{e} i^{l}}\right]<1+i^{l}\left(1-\tau_{M}\right)$, the output of $\frac{\left(1+i^{l}\right)(\theta+\eta)}{1+i^{l}\left(1-\tau_{M}\right)}$ will be smaller than $\frac{\left(1+i^{l}\right)(\theta+\eta)}{1+i l^{l}\left(\frac{\left.1-\tau_{M}\right)}{\left(2-\tau_{M}\right)}\left[\frac{1+i^{l}}{1+i^{l}-\tau_{e} i^{i}}\right]\right.}$ and $f^{\prime}(k)$ will be added, comparing to the situation of absence of securities. Accordingly, and given that $\mathrm{f}^{\prime \prime}<0$ is assumed, the amount of per capita capital (and consequently, per capita production, consumption, and welfare) will decrease. So the economy is getting worse than before. In other words, economic growth has slowed down.

So far, we have introduced the effect and results of securitization using a mathematical model. But, the question is if the simulation of real economies' behavior would be actually attainable? The answer is positive; we can 
anticipate them. We apply the calibration method using structural parameters and relationships for a real economy in the ordinary form. In the following research model, two diversified quantities under steady-state equilibrium have been solved and compared for two different strict conditions: the model along with securitization and non-securitization.

\section{Data and Summary Statistics}

In this segment, using structural parameters of the US economy, the dynamics of the last analytical model have been simulated; results are recorded in Table 1.

Table 1

Structural parameters of the US economy

\begin{tabular}{lll}
\hline Source & Value & Parameter \\
\hline Federal Reserve Bank of Saint Louis & 0.0112 & Population growth rate $(\eta)$ \\
Andreoni and Sprenger (2012) & 0.3 & Time preference rate $(\theta)$ \\
Feinman (1993) & 0.1 & Ratio of legal Reserves $\left(\tau_{M}\right)$ \\
Federal Reserve Bank of Saint Louis & 0.8 & Technology Index (a) \\
Jones (2003) & 0.45 & $\begin{array}{l}\text { Production elasticity of capital } \\
(\propto)\end{array}$ \\
\hline
\end{tabular}

Source: Research Findings

In the process of the model solution, DYNARE program has been used under Matlab 4.6.1 software. The stimulated variable with securitization as well as non-securitization obtained as following in Table 2:

Table 2

Stimulated Results under Strict Securitization and Non-securitization Conditions

\begin{tabular}{lll}
\hline Securitization (0.20) & Non-securitization $(\mathbf{0 . 3 5})$ & Variable \\
\hline 4.80235 & 7.16313 & $\mathrm{k}$ \\
1.78355 & 1.80858 & $\mathrm{c}$ \\
2.14023 & 1.35977 & $\mathrm{p}$ \\
3.47093 & 2.53645 & $\mathrm{~W}$ \\
0.42031 & 0.205922 & $\mathrm{r}$ \\
4 & 1.85714 & $\mathrm{l}$ \\
\hline
\end{tabular}

Source: Research Findings (Extracted from DYNARE software) 
A comparison between two strict conditions finds out that per capita capital and per capita consumption will decrease under securitization, and a price index, wage rate, rate of capital return, and loan value would increase.

Indeed, the banks commit to securitization; they can offer their funds to agents. So securitization process induces an increase in credit capacity, and finally, the loan values will be much more than the non-securitization conditions. In other words, the loan value has been increased from 1.85 to 4 units.

On the other hand, an increase in credit and money supply, due to securitization, impacts the economy in the same way as an external shock, which induces an increase in the price index from 1.35 to 2.14 ; recent increase is on a higher level than before and creates an inflationary condition. On the other hand, the mentioned inflationary environment itself causes a systematic risk which finally converges investment and per capita capital toward a lower level than before. In this regard, securitization makes per capita capital from 7.16 units to 4.8 units which it brings down produce and consumption level from 1.80 to 1.78 units.

The results show an increase in wage rate from 2.53 to 3.47. Since bank securitization raises loan funds received by firms, it increases demand for the labor force and household capital, increasing wage rate and price index. Ultimately, the results stemmed out from the simulated model confirm that of a mathematical model.

\section{Conclusion}

It follows from the above that, due to the shadow banking system and the securitization of bank assets, the amount of per capita capital and thus economic growth will decline in the long run. In contrast with common sense, the rework effect of securitization on per capita capital and economic growth will be observable in the long run. Through securitization, banks have increased the capacity to create credit, which has no backing and, has negative effects (such as; decrease in per capita capital and subsequently a decrease in consumption and economic growth) on the economy. In other words, in the common securitization process in banks, the issuer issues securities backed by a debt account. So credits created through securities do not match quality criteria and have negative implications for the economy.

In contrast to securities by the conventional bank, Sukuk (Islamic securities), by required backing for credit creation, has no negative effects on conventional securities. Therefore, banks are advised to apply Islamic securities based on the real sector of the economy to finance capital needs. As 
a logical conclusion, expanding Islamic securities could be an appropriate alternative to boost economic growth in any economy. Still, the establishment of central management for the capital assets market, regulating and supervising intermediary financial institutions, and disclosing information and statistics related to the issuance of Islamic securities can be an effective step towards developing a structured and interpreted security market.

\section{References}

Andreoni, J. \& Sprenger, C. (2012). Estimating Time Preferences from Convex Budgets, American Economic Review, 102(7), 3333-56.

Ata, C. B., \& Gong, D. (2014). Securitization, Financial Stability and Macroeconomy: Evidence from an international. Tilburg University. http://ies.fsv.cuni.cz/default/file/get/id/26480

Blanchard, O. J., \& Fischer, S. (1993). Lecture Notes on Macroeconomics, London: The MIT Press https://mitpress.mit.edu/books/lectures-macroeconomics.

Chao, Ch., Shan, M. E., \& Zhang, J. (2017). Shadow Banking and Economic Development in Developing Countries: Evidence from China. 204892516. https://www.semanticscholar.org/paper/Shadow-Banking-and-EconomicDevelopment-in-Evidence-Chao-Ee/5e52c796a970c52034aa17245ebf2641610b036a

Chen, J., \& Zhang, X. (2012). The Impact of Shadow banking System on China's Economic Development - based on the analysis of quarterly data from 20002010, Journal of Research on Financial and Economic Issues, 8, 66-72.

Christiano, L. J. (1991). Modeling the Liquidity Effect of a Money Shock, Federal Reserve Bank of Minneapolis Quarterly Review, 15(1), 3-34.

Ebrahimi, B., \& Vaez, B. M. (2012). Theoretical Analysis of the Impact of Credit Creation on the Financial Crisis. Quarterly Journal of Islamic Economics, 5(2), 27-50.

Ebrahimi, B. (2015). Development of a Theoretical Model of Financial Crises Due to Financial Leverage, $\mathrm{PhD}$ thesis, Faculty of Administrative Sciences and Economics, University of Isfahan.

Fabozzi, F. J., \& Kothari, V. (2008). Introduction to Securitization. Series Book 174, 1st Edition, Kindle Edition.

Feghhi, K. M. (2006). Transforming into Securities of Assets (Loans) in the Banking Industry. Tehran: Monetary and Banking Research Institute, 1-120.

Feinman, J. N. (1993). Reserve Requirements: History, Current Practice, and Potential Reform, Federal Reserve Bulletin, 79(6), 569-589.

Fry, M. (1995). Financial Development in Asia: some analytical issues, Asian Pacific Economic Literature, 9(1), 40-57.

Jones, C. I. (2003). Growth, Capital Shares, and a New Perspective on Production Functions. Mimeo, University of California Berkeley.

King, R. \& Levine, R. (1993). Finance, Entrepreneurship and Growth Theory and Evidence. Journal of Monetary Economics, 32(3), 513-542. 
Manjoo, F. A. (2005). Securitization: An Important Recipe for Islamic Banks-A Survey. Review of Islamic Economics, 9(1), 1-53.

Najafi, M. (2006). Reviewing the Financing Process through the Issue of Sukuk. Journal of Bourse, 53, 36-43.

Ramsey, F. P. (1928). A Mathematical Theory of Saving. The Economic Journal, 38(152), 543-559.

Stiglitz, J. (2009). The Anatomy of a Murder: Who Killed America's Economy? Critical Review, $21(2 \& 3)$.

Zandieh, V., \& Zandieh, S. (2015). The Position of Securitization in the Economic Growth and Development of the Countries (Emphasizing the Need for the Development of the Securities Market in Iran). Quarterly Journal of Investment Knowledge, 4(16), 221-240.

Zhou, Sh., \& Tewari D. D. (2020). The Impact of Shadow Banking on Economic Growth: Evidence from Cross Country Data (2006-2018), Journal of International Commerce, Economics and Policy, 11(3), 2050010. https://doi.org/10.1142/S1793993320500106

Zhou, S. \& Tewari. D. (2018). Political Institutions and Macroeconomic Factors as Determinants of Credit Risk in South Africa. Journal of Economics and Behavioral Studies, 10(6(J), 211-221. https://doi.org/10.22610/jebs.v10i6(J).2611 


\section{Attachments}

1) Diagram of adjusting the equilibrium values from the conditions of the nonexistence of securities to the conditions of existence of securities
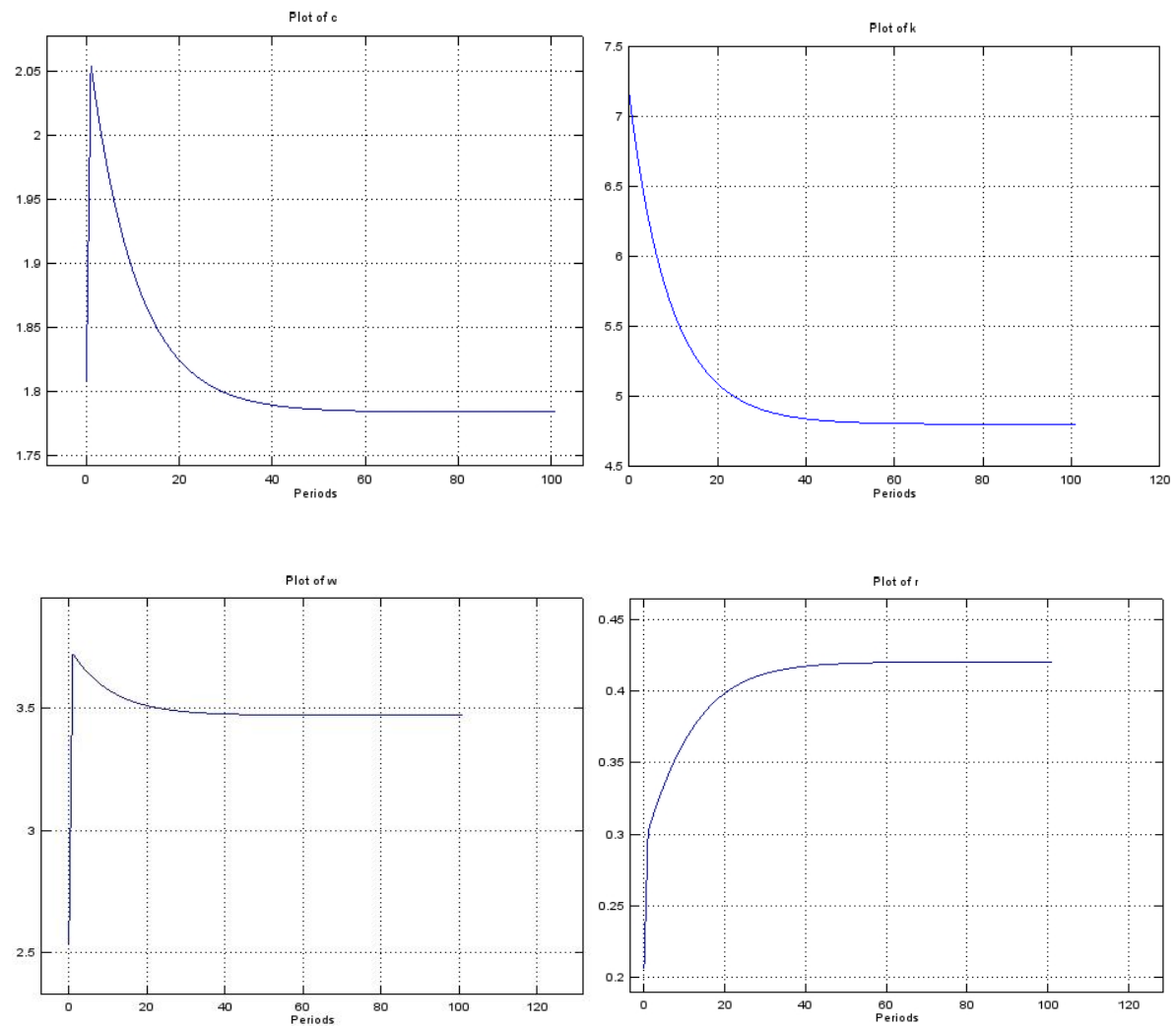

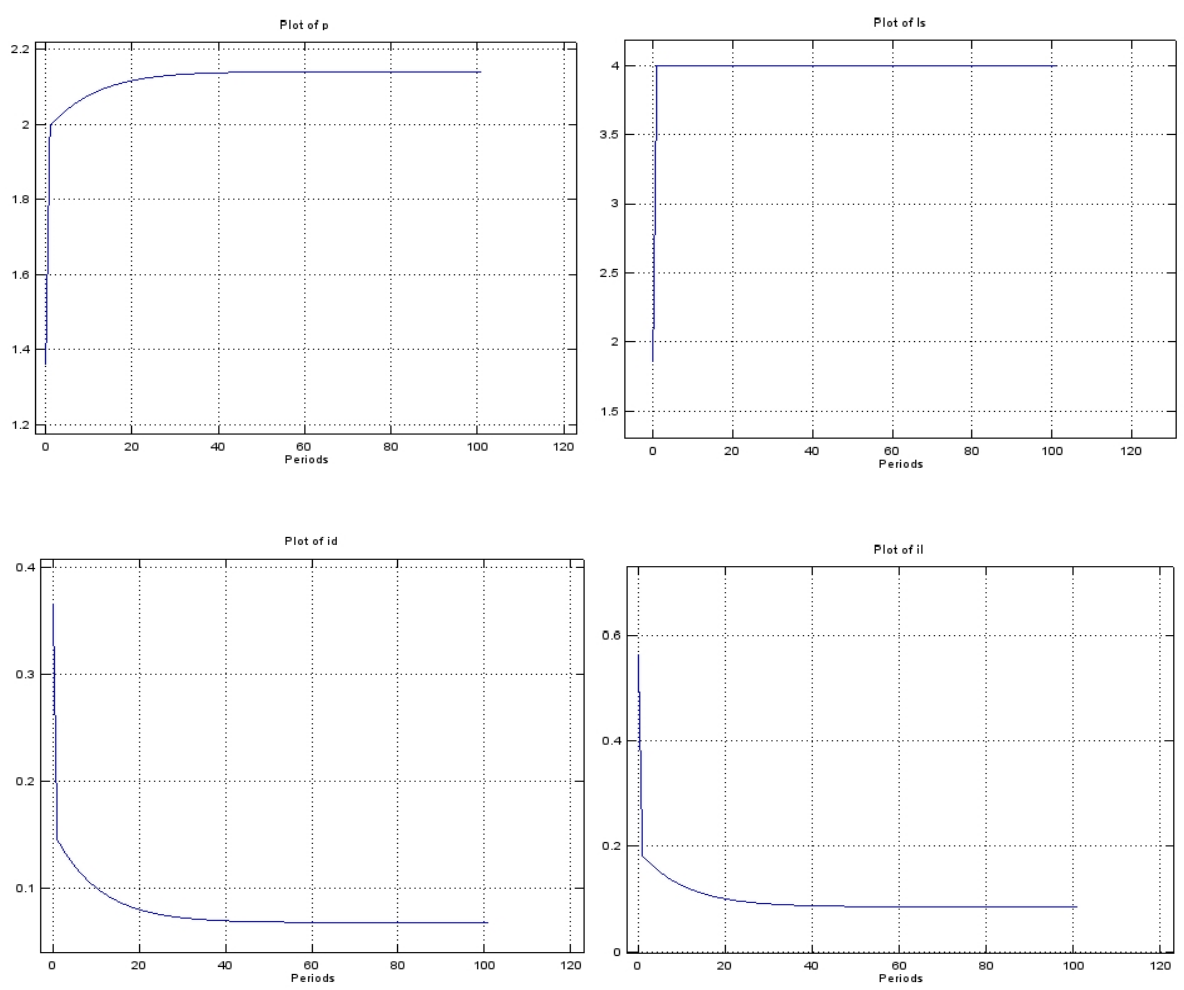

2) The software codes are as follows:

/* Codes of Model

* University of Isfahan */

var ls, ld, il, id, k, r, p, w, c;

varexo tau;

parameters delta, a, nou, alpha;

delta $=0.3$;

a $=1.48$

alpha $=0.35$;

nou $=0.08$;

model;

ls $=(1-\mathrm{tau}) / \mathrm{tau}$;

id $=(1-$ tau $) * \mathrm{il}$;

ld $=\mathrm{r}^{*} \mathrm{p} * \mathrm{k}(-1) /(1+$ nou $)$;

ld $=\mathrm{ls}$;

$\mathrm{r}=$ alpha $*(1+$ nou $) *(1+\mathrm{id}) /(\operatorname{tau} * \mathrm{k}(-1))$;

$\mathrm{w}=(1+\mathrm{id}) *(1-\mathrm{alpha}) / \mathrm{tau}$; 
$\mathrm{p}=(1+\mathrm{id}) *(1+\mathrm{nou})^{\wedge}$ alpha $/\left(\mathrm{a} * \mathrm{k}(-1)^{\wedge}\right.$ alpha*tau $)$;

$(1 / \mathrm{c})=1 /(1+$ delta $) *(((1+\mathrm{id}(+1)) * \mathrm{r}(+1) / \mathrm{p}(+1))+1 /(1+$ nou $) *(1 / \mathrm{c}(+1)))$;

$\mathrm{k} \quad=-\mathrm{c}+\mathrm{a}^{*} \mathrm{k}(-1)^{\wedge}$ alpha/ $(1+\text { nou })^{\wedge}$ alpha $+(1-$ nou $) * \mathrm{k}(-1) /(1+$ nou $) ;$

end;

\begin{tabular}{|c|c|c|}
\hline initval; & endval; & simul (periods=100); \\
\hline $\begin{array}{l}\text { tau=0.35; } \\
\mathrm{c}=6 \\
\mathrm{il}=0.1 \\
\mathrm{id}=0.065 \\
\mathrm{r}=0.1 \\
\mathrm{w}=18.5 \\
\mathrm{ls}=1.85 \\
\mathrm{ld}=1.85 \\
\mathrm{p}=2.5 \\
\mathrm{k}=14\end{array}$ & $\begin{array}{l}\text { tau }=0.20 \\
\mathrm{c}=6 \\
\mathrm{il}=0.1 \\
\mathrm{id}=0.065 \\
\mathrm{r}=0.1 \\
\mathrm{w}=18.5 \\
\mathrm{ls}=1.85 \\
\mathrm{ld}=1.85 \\
\mathrm{p}=2.5 \\
\mathrm{k}=14\end{array}$ & $\begin{array}{l}\text { rplot k; } \\
\text { rplot c; } \\
\text { rplot ls; } \\
\text { rplot r; } \\
\text { rplot id; } \\
\text { rplot il; } \\
\text { rplot p; } \\
\text { rplot w; }\end{array}$ \\
\hline
\end{tabular}

